\title{
SISTEM INFORMASI PRESENSI KARYAWAN
}

\author{
${ }^{1}$ Rice Novita ${ }^{2}$ Fachrozi Ramadhan Hardi \\ Jurusan Sistem Informasi, Universitas Islam Negeri Sultan Syarif Kasim \\ Jl. HR.Soebrantas KM.18 Panam Pekanbaru-Riau \\ Email: rice.novita@uin-suska.ac.id, framadhanhradi@gmail.com.
}

\begin{abstract}
ABSTRAK
Absensi kehadiran pegawai merupakan faktor penting bagi sebuah instansi atau perusahaan untuk mencapai tujuan, hal ini berkaitan pada kedisiplinan dan berdampak pada kinerja dari masing-masing pegawai. Oleh karena itu, perlu adanya pendataan khusus untuk mencatat absensi kehadiran dan ketidak hadiran agar aktifitas kerja dapat tercatat secara realtime dan baik. Banyak cara yang dapat dilakukan untuk mencapai sistem informasi absensi yang baik, salah satunya menggunakan teknologi komputer dimana penerapannya dengan aplikasi absensi berbasis website. Pada PT. Swadaya Absi Manunggal-Jereh consortium sistem yang digunakan dalam proses absensi masih manual menggunakan buku absensi harian yang berdampak pada efisiensi dan efektifitas pendataan, pencarian data sekaligus perhitungan rekap data yang membutuhkan waktu yang relatif lama. Disamping itu resiko kesalahan dan kehilangan data absensi semakin besar. Berdasarkan permasalahan diatas dibuatlah Sistem Informasi Absensi Karyawan Pada PT.Swadaya Abdi Manunggal-Jereh consortium. Metode penelitian merupakan metode yang digunakan dalam pengumpulan data yang meliputi: metode observasi, wawancara dan studi pustaka. Sedangkan pengembangan perangkat lunak menggunakan waterfall yang meliputi : analisa kebutuhan, desain, pengkodean, pengujian dan implementasi. Dengan dihasilkannya sistem absensi karyawan berbasis web dapat memberikan kemudahan dalam proses absensi, pencarian data dan perhitungan rekap absensi, serta meminimalisir kehilangan dan kesalahan pencatatan data absensi pada PT. Swadaya Abdi Manunggal-Jereh consortium.
\end{abstract}

Kata Kunci: Sistem Informasi, Absensi Karyawan, Berbasis Web

\section{A. PENDAHULUAN}

Teknologi informasi sangat dibutuhan dalam kehidupan sehari-hari untuk mempermudah kinerja manusia agar mendapatkan informasi yang cepat, tepat, dan akurat. Begitu pula dengan sistem informasi untuk memasukkan, mengelola, memanipulasi, menganalisa, mengumpulkan, menampilkan serta menghasilkan serta menghasilkan data untuk dilakukan pengujian, penggabungan serta pengamanan manajemen yang ditujuan untuk mendukung segala perencanaan di masa mendatang. Sistem informasi adalah suatu jaringan kerja dari prosedur-prosedur yang saling berhubungan, berkumpul bersama-sama untuk melauan suatu kegiatan atau untuk menyelesaikan suatu sasaran yang tertentu[1][2].

Penggunaan teknologi informasi ditentukan oleh berbagai faktor, antara lain yang sangat mempengaruhi optimalisasi penggunaan teknologi informasi adalah ketersediaan [3]. Kebutuhan akan perangkat teknologi informasi berkembang seiring dengan kemajuan organisasi. Faktor availability dan keandalan dari perangkat teknologi informasi juga umumnya akan menjdi sangat penting karena aspek ketergantungan terhadap teknologi informasi juga semakin besar. oleh karena itu perlu diadakan

CPI dan kementrian lingkungan hidup. Namun dari semua jasa yang ada di perusahaan ini masih ada kekurangan yaitu, pada bidang sistem informasi. Terutama pada absensi kehadiran pegawai PT. SAM-Jereh yaitu masih manual. evaluasi terhadap kebutuhan perangkat teknologi informasi [4]. Salah satu perangkat yang digunakan dalam penerapan teknologi informasi adalah komputer. Manfaat dari penggunaan komputer antara lain yaitu memudahan pekerjaan sehari hari baik dalam urusan administrasi maupun perhitungan konstruksi, dan menjadikan pekerjaan yang dapat dikerjakan dengan lebih cepat.

PT. Sam-Jereh adalah perusahaan yang bergerak di bidang migas yang menawarkan jasa service pada pada PT. Chevron Pasific Indonesia, jasa yang ditawarkan adalah pompa injeksion limbah dari PT CPI . Limbah yang dimaksud adalah minyak mentah bumi yang tidak bisa dipakai atau di proses lagi oleh PT. CPI. Karena di dalamnya mengandung semua sampah seperti kayu, pasir, batu yang ada pada limbah dipisahkan dari limbah. Sebelum di injeksikan ke sumur chevron sebelumnya dilakukan penyaringan sesuai dengan peraturan kementrian lingkngan hidup. PT. Sam-Jereh juga memiliki aturan-aturan yang harus dipatuhi dari CPI. Salah satu aturan yang harus diperhatikan adalah konsentrasi limbah sebanyak 20\% limbah cair $80 \%$ air yang diaduk secara bersamaan, penyaringan ini yang di maksud adalah pemisahan dengan alat yang disediakan oleh PT. Sam-Jereh. Dan setiap harinya dilaporkan kepada

\section{B. LANDASAN tEORI B.1 Sistem}

Sistem merupakan suatu kumpulan komponen - komponen yang membentuk sutau 
kesatuan. Sebuah organisasi dan sistem informasi adalah sistem fisik dan sosial yang ditata sedemikian rupa untuk mencapai tujuan tertentu [5].

Sedangkan menurut penulis sistem merupakan interaksi antara perangkat lunak yang terdapat didalam sebuah komputer yang sering melakukan pertukaran atau transaksi data sehingga menghasilkan pencapaian atau tujuan yang sama.

\section{B.2 Karakteristik Sistem}

supaya sistem itu dikatakan sistem yang baik memiliki karakteristik yaitu [6]:

a. Komponen Suatu sistem terdiri dari sejumlah komponen -komponen yang saling berintraksi, yang artinya saling bekerjasama membentuk satu kesatuan.

b. Batasan Sistem Merupakan daerah yang membatasi antara suatu sistem dengan sistem yang lain atau dengan lingkungan luarnya.

c. Lingkungan Luar Sistem Merupakan diluar batsan dari sistem yang memepengaruhi operasi sistem.

d. Penghubungan Sistem Merupakan media penghubung antara satu subsustem dengan subsistem lainnya.

e. Masukan Sistem Adalah energi yang dimasukkan kedalam sistem, yang dapat berupa perawatan ( maintenance input ), dan masukan sinyal( signal input ).

f. Keluaran sistem ( Output ). Merupakan hasil energi yang diolah dan diklasifikasikan menjadi keluaran yang berguna.

g. Pengolahaan Sistem Suatu sistem menjadi bagian pengolah yang akan merubah masukan menjadi keluaran.

h. Sasaran Sistem Sasaran dari sistem sangat menentukan input yang dibutuhkan sistem dan keluaran yang dihasilkan sistem.

\section{B.3 Informasi}

Informasi dapat didefinisikan sebagai hasil dari pengolahan data dalam suatu bantuk yang lebih berguna dan lebih berarti bagi penerimanya yang menggambarkan suatu kejadian - kejadian ( ivent ) yang nyata ( fact ) yang digunakan untuk pengambil keputusan [6]

Fungsi utama informasi adalah menambah pengentahuan. Informasi yang disampaikan kepada pemakai mungkin merupakan hasil data yang sudah diolah menjadi sebuah keputusan. Akan tetapi, dalam kebanyakan pengambilan keputusan yang kompleks, informasi hanya dapat menambah kemungkinan kepastian atau mengurangi bermacam-macam pilihan [7]

\section{B.4 Sistem Informasi}

Sistem Informasi (SI) adalah kombinasi dari teknologi informasi dan aktivitas orang yang menggunakan teknologi itu untuk mendukung operasi dan manajemen. Dalam arti yang sangat luas, istilah sistem informasi yang sering digunakan merujuk kepada interaksi antara orang, proses algoritmik, data, dan teknologi. Dalam pengertian ini, istilah ini digunakan untuk merujuk tidak hanya pada penggunaan organisasi teknologi informasi dan komunikasi (TIK), tetapi juga untuk cara di mana orang berinteraksi dengan teknologi ini dalam mendukung proses bisnis.

Sistem informasi adalah gabungan yang terorganisasi dari manusia, perangkat lunak, perangkat keras, jaringan komunikasi dan sumber data dalam mengumpulkan, mengubah, dan menyebarkan informasi dalam organisasi.

\section{B.5 Absensi}

Absensi atau kartu jam hadir adalah dokumen yang mencatat jam hadir setiap karyawan di perusahaan. Catatan jam hadir karyawan ini dapat berupa daftar hadir biasa, dapat pula berbentuk kartu hadir yang diisi dengan mesin pencatat waktu. Pekerjaan mencatat waktu pada dasarnya dapat dipisahkan menjadi dua bagian yaitu pencatatan waktu hadir (attendance time keeping) dan pencatatan waktu kerja (shop time keeping).

Pencatatan waktu hadir dimaksudkan untuk mengumpulkan data mengenai jumlah jam hadir karyawan dalam suatu periode pembayaran dan kadang-kadang juga mengenai tarif upah untuk pekerjaan yang dilakukan. Pencatatan waktu kerja dimaksudkan untuk mencatat jam kerja sesungguhnya yang digunakan oleh karyawan dalam setiap pekerjaan (job) atau departemennya. Catatan waktu kerja ini dapat digunakan untuk mengecek catatan waktu hadir dan juga mendapatkan data produksi yang diperlukan untuk distribusi upah dan gaji dan perhitungan intensif.

\section{B.6 Unified Modeling Language ( UML )}

Unified Modeling Language (UML). Merupakan alat perancangan sistem yang berorientasi pada objek. Secara filosofi kemunculan UML dipahami oleh konsep yang telah ada yaitu konsep pemodelan Object oriented (OO), karena konsep ini menganlokasikan sistem seperti kehihupan nyata yang didominasi oleh obyek dan gambar atau dinotasikan dalam simbol - simbol yang cukup spesifik maka OO memiliki proses standard dan bersifat independen (Haviluddin, 2011).

Diagram UML Yang Digunakan :

a. Use Case Diagram

Use case diagram mengambarkan fungsionalitas yang diharapkan sebuah system. Yang ditekankan adalah "apa" yang diperbuat system, dan bukan "bagaimana". Sebuah use case mempersentasikan sebuah interaksi antara actor dengan system. Use case merupakan 
sebuah pekerjaan tertentu, misalnya login kesistem, meng-create sebuah daftar belanja dan sebagainya ( [8]

b. Activity Diagram

Activity Diagram menggunakan aliran fungsionalitas sistem. Dapat juga digunakan untuk menggambarkan aliran kejadian (flow of events) dalam use case. Aktivitas dalam digram dipersentasikan dengan bentuk bujur sangkar bersudut tidak lancip, yang didalamnya berisi langkah-langkah apa saja yang terjadi dalam aliran kerja.

c. Sequence Diagram

Sequence Diagram digunakan untuk menunjukkan aliran fungsionalitas.

d. Class Diagram

Class Diagram menunjukkan interaksi antara kelas dalam sistem. Kelas mengandung informasi dan tingkah laku yang berkaitan dengan informasi tersebut. Sebuah kelas pada diagram kelas dibuat untuk setiap tipe objek pada diagram sekuensial atau diagram kolaborasi.

\section{METODOLOGI PENELITIAN}

\section{C.1 Model Waterfall}

Metode

pengembangan

sistem sequensiallinier atau yang sering disebut dengan siklus kehidupan klasik atau model air terjun (model Waterfall) memberikan sebuah pendekatan pengembangan sistem yang sistematik dan sekuensia, dimulai pada fase perencanaan sistem, analisis, desain, kode , pengujian dan pemeliharaan.

Setiap fase pada Waterfall dilakukan secra berurutan namun kurang dalam interasi pada setiap level. Dalam pengembangan sistem informasi berbasis web, Waterfall memiliki kemamapuan untuk kembali pada proses sebelumnya apabila terjadi kesalahan dalam tahap pembuatan. Dapat dilihat pada Gambar 1

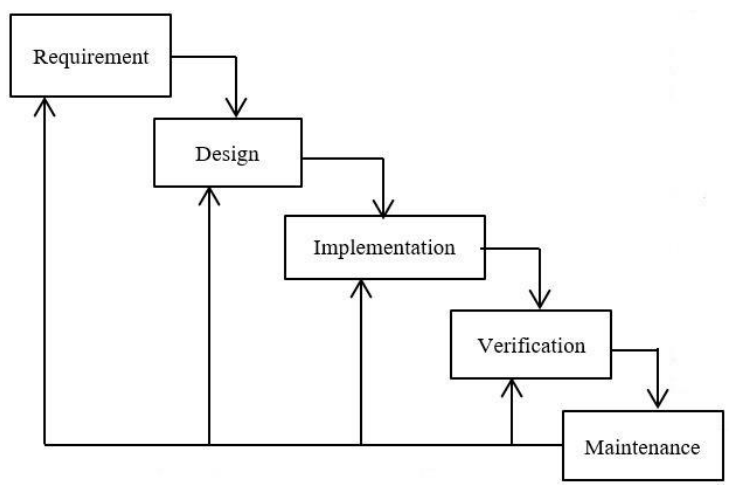

Gambar 1. Metode Waterfall

Dalam tahap ini, pengembangan sistem informasi pengelolahan data Kerja Praktek hingga tahapan Implementation, dengan rincian fase sebagai berikut:

1. Requirement
Menganalisa kebutuhan dari software yang dibutuhkan dalam pengembangan sistem. Dalam fase ini keguaan software yang diharapkan dan batasan softwar. Untuk mengetahui sifat program yang akan dibuat.

2. Design

Spesifikasi kebutuhan dari tahap sebelumnya akan dipelajari dalam fase ini desain sistem disiapkan. Desain sistem membantu dalam menentukan perangkat keras (hardware) dan juga membantu dalam mendefenisikan arsitektur sistem secara keseluruhan. Desain harus dapat mengimplementasikan kebutuhan yang telah disebutkan pada tahap sebelumnya.

3. Implementation

Pada tahap ini, sistem pertama kali dikembangkan diprogram kecil yang disebut unit, yang terintegrasi dalam tahap selanjutnnya. Setiap unit dikembangkan dan diuji untuk fungsionalitas yang disebut unit testing.

4. Integration

Seluruh unit yang dikembangkan dalam tahap implementasi diintegrasikan ke dalam sistem setelah pengujian yang dilakukan masingmasing unit.setelah integrasi seluruh sistem diuji untuk mengecek setiap kegagalan maupun kesalahan.

5. Maintenance

Tahap akhir dalam model waterfall. Perangkat lunak yang sudah jadi, dijalankan serta dilakukan pemeliharaan. Pemeliharaan termasuk dalam memperbaiki kesalahan yang tidak ditemukan pada langkah sebelumnya.

\section{C.2 PHP}

PHP merupakan secara umum dikenal sebagai bahasa pemograman script-script yang membuat dokumen HTML secara on the fly yang dieksekusi diserver web, dokumen HTML yang dihasilkan dari suatu aplikasi bukan dokumen HTML yang dibuat dengan mengunakan editor teks atau editor HTML dikenal juga sebagai bahasa pemograman server side .

\section{C.3 MySQL}

MySQL adalah program database yang mampu mengirim dan menerima data dengan sangat cepat dan multi user. MySQL memiliki dua bentuk lisensi, yaitu free software dan shareware. MySQL free Software karena bebas menggunakan database ini untuk keperluan pribadi atau usaha tanpa membeli atau membayar lisensi. [9].

\section{ANALISA DAN HASIL}

\section{D.1 Analisis Sistem}

Analisis memegang peranan yang penting dalam membuat rincian sistem baru. Analisis perangkat lunak merupakan langkah pemahaman persoalan sebelum mengambil tindakan atau keputusan penyelesaian hasil utama. Sedangkan 
setiap tahap perancangan sistem adalah membuat rincian sistem hasil dari analisa menjadi bentuk perancangan agar dimengerti oleh pengguna.

Setelah mempelajari teori-teori tentang perangkat lunak dan sistem pada bab sebelumnya, maka bab ini akan lebih difokuskan pada penjelasan tentang analisa dan perancangan perangkat lunak yang nantinya akan diimplementasikan dan diberi nama "Sistem Informasi Absensi Karyawan ".

\section{D.2 Analisis Sistem yang Sedang Berjalan}

Dari hasil analisis sistem yang sedang berjalan saat ini pada bagian Absensi karyawan di PT SAM-Jereh Duri terdapat beberapa masalah. Permasalahan tersebut ialah sistem pengolahan data absensi denagn cara manual, ditulis di lembar kertas yang menyebebkan terjadinya human error dan kurang efektif untk mencari data absen yang sudah ditulis.

Berikut penjelasan alur sistem lama, pertama-tama karyawan berangkat menuju kantor. Kemudian setiba di kantor karyawan menuju ke bagian admin, tiba di bagian admin karyawan menunjukkan name tag kepada admin. Lalu karyawan mengisi absen masuk yang di tulis pada lembaran kertas absen. Setelah mengisi absen di kantor karyawan menuju ke lokasi kerja. Karyawan melaksanakan agenda pekerjaan, setelah selesai bekerja pada waktu yang ditentukan, karyawan kembali menuju kantor. Karyawan menuju ke meja admin, karyawan lalu mengisi absen pulang, dan karyawan kembali pulang.

\section{D.3 Analisis Sistem Usulan}

Sistem yang akan dibangun adalah sistem informasi pengolahan data. Sistem ini bertindak sebagai menampilkan data absensi karyawan, meelihat,menyimpan,dan menambah data yang ada. Sistem informsi pengolahan data absensi karyawan ini akan memiliki satu pengguna, yaitu salah satu karyawan atau user dan admin . Perancangan sistem usulan akan memberikan gambaran secara detail mengenai bentuk dan rancangan kerja dari sistem usulan dalam menyelesaikan masalah yang sedang terjadi.

Sistem informasi yang diusulkan akan berbentuk sebuah tampilan sistem yang didalamnya terdapat 7 button, juga berupa form untuk menambah data-data karyawan yang ada di SAM. Fitur yang ada di sistem nantinya adalah manajemen user, bagian, karyawan, jabatan, transaksi absensi masuk, transaksi absensi keluar laporan absensi bulanan(disertai degan print/cetak). Dengan adanya sistem ini diharapkan dapat mengatasi permasalahan yang ada pada sistem yang lama. Keamanan dalam sistem juga disediakan yaitu berupa menu login yang berfungsi untuk memberikan hak akses kepada admin atau karyawan untuk mengelola sistem tersebut.

\section{D.4 Rencana Sistem Usulan}

Setelah melakukan analisis sistem lama dan sistem usulan, maka tahapan selanjutnya ialah melakukan perancangan sistem usulan. Menurut Kristanto (2008), perancangan sistem ialah suatu fase diperlukan suatu keahlian perancangan untuk elemen-elemen komputer yang akan menggunakan sistem yaitu pemilihan peralatan dan program komputer untuk sistem yang baru. Diagram UML yang digunakan dalam perancangan aplikasi antrian ini adalah use case diagram, sequence diagram, dan activity diagram.

\section{D.5 Use Case Diagram}

Use case diagram dari sistem yang diusulkan:

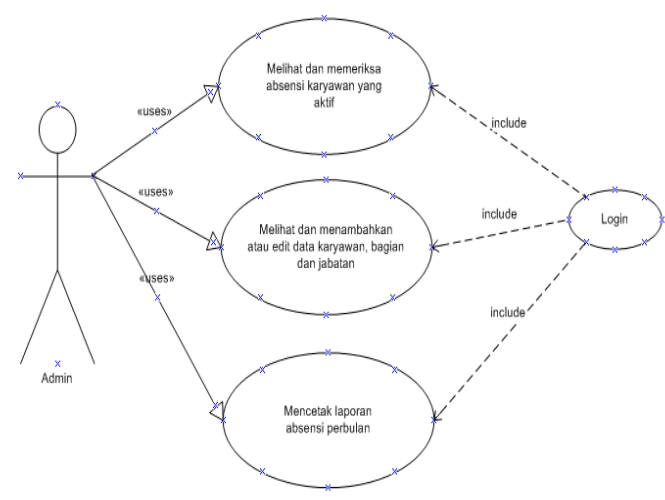

Gambar 2 Use case diagram sistem usulan Pada gambar 2 menjelaskan hubungan antara aktor dan use case. Terdapat empat use case pada aktor admin. 


\section{6 Sequence Diagram}

Sequence diagram dari sistem yang diusulkan:

1. Sequence diagram login

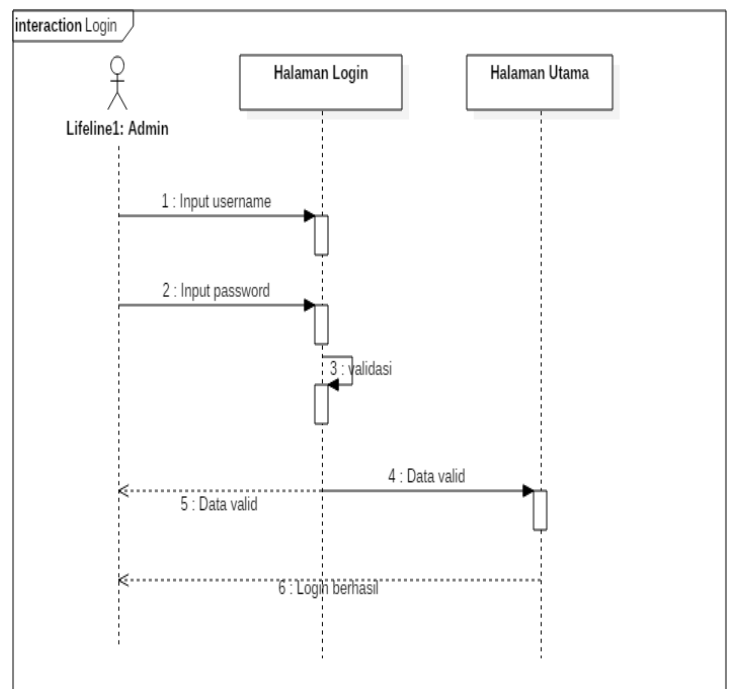

Gambar 3. Sequence diagram login

Pada gambar 3 merupakan sequent diagram yang mejelasakan hubungan antara objek dalam sistem. Sequent diagram menjelasakan masing masing kegiatan dari use case.

\section{D.7 Activity Diagram}

1. Activity diagram login

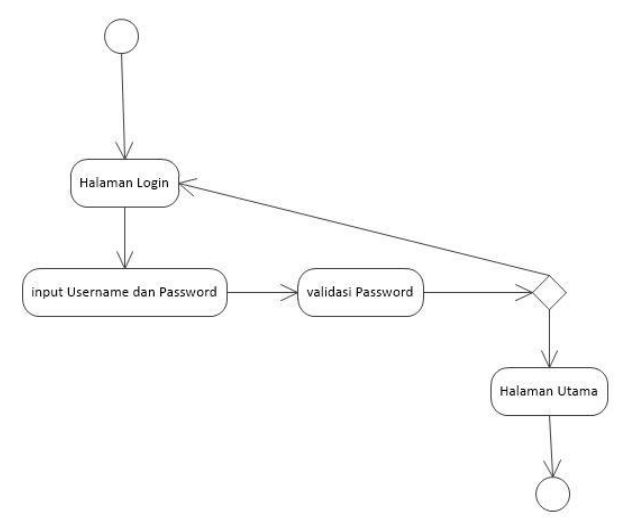

Gambar 4 Activity diagram login

Pada gambar 4 merupakan activity diagram yang mejelasakan langkah langkah masing objek. Dari setiap usecase yang dihasilkan.

\section{D.8 Class Diagram}

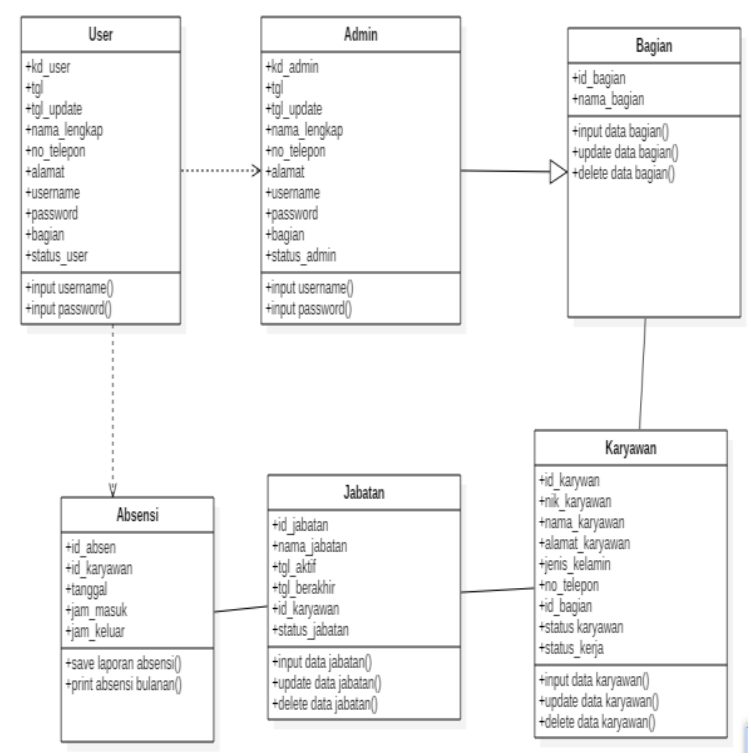

Gambar 5. Class Diagram

Pada gambar 5 merupakan class diagram, yang menggambarakn hubungan antar class. Dan terdapat enam class dalam sistem yang dibangun.

\section{E. Hasil}

Setelah tahap perancangan kebutuhan sistem dilakukan maka langkah selanjutnya adalah mengimplementasikan hasil rancangan tersebut kedalam sistem yang akan dibuat. Agar hasil sistem dapat sesuai dengan kebutuhan maka terlebih dahulu dilakukan perancangan tampilan yang akan dibahas lebih lanjut pada sub-bab ini.

\section{Tampilan login}

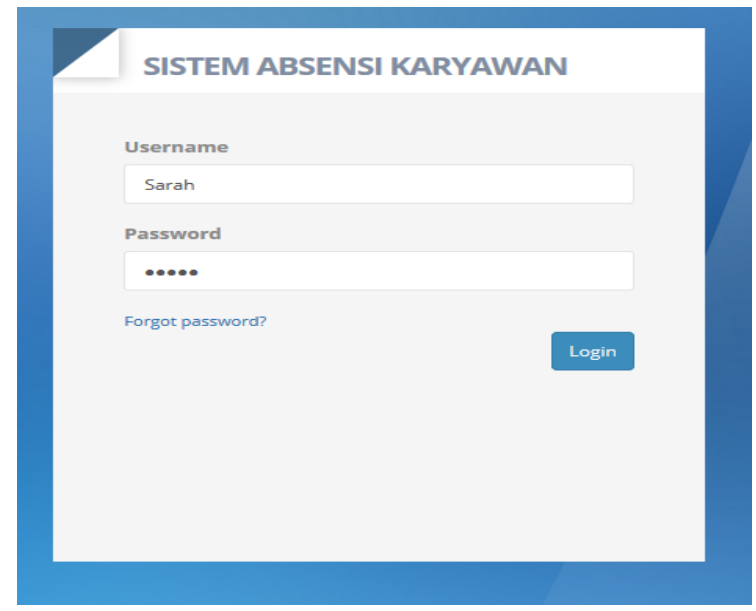

Gambar 6. Rancangan tampilan login user 
Pada gambar enam merupakan tampilan login, setiap user yang akan mengisi absen diwajibkan untuk login dulu. Terdapat dua field yaitu user name dan password.

\section{Halaman Utama}

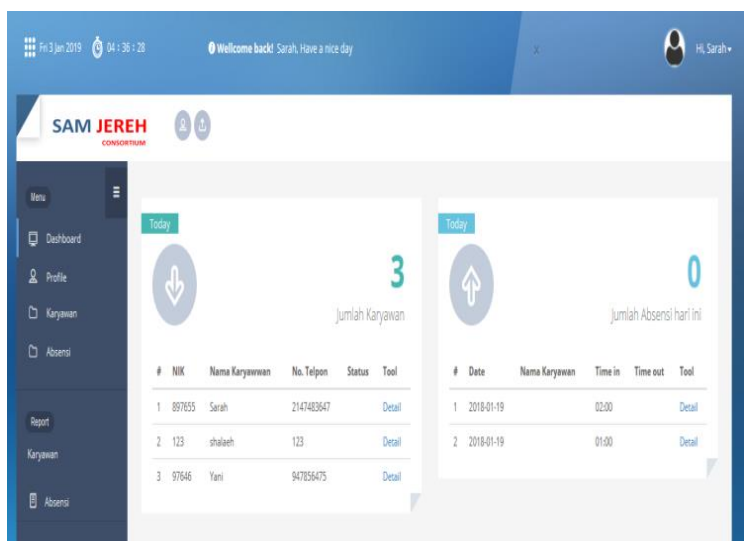

Gambar 7. Halaman utama

Pada gambar tujuh merupkan tampilan halaman utama. Setelah user melakukan login.

\section{Halaman Form User dan Karyawan}
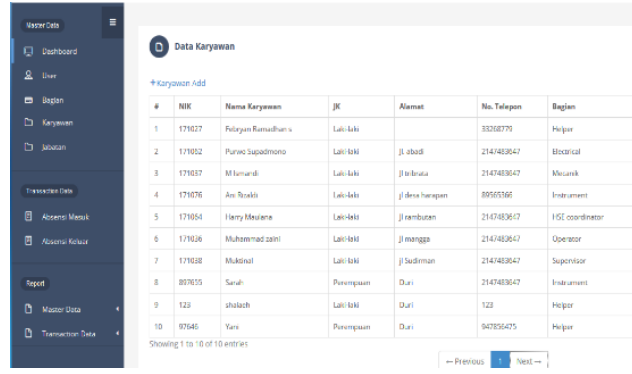

$\infty$

Gambar 8. Halaman utama

Pada gambar delapan merupakan form admin dan karyawan. Berisi menu menu yang dibutuhkan.

3. Halaman form data Absensi masuk dan keluar
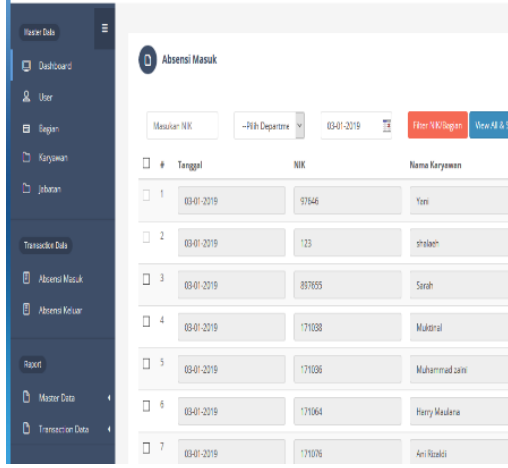

Gambar 9. Halaman data masuk dan Keluar

\section{E.1 Kesimpulan}

Sistem Informasi Absensi Karyawan pada PT. Swadaya Abdi Manunggal-Jereh consortium. maka dapat diambil kesimpulan sebagai berikut :

1. Dengan adanya sistem dan perancangan ini, menjadikan proses absensi pengolahan data karyawan bisa lebih cepat dan mudah.

2. Admin dapat melihat user atau karyawan yang absensi masuk dan keluar yang ditampilkan pada halaman admin.

3. Selain melihat, admin juga dapat mencetak pengolahan data absen yang telah di jumlahkan selama sebulan untuk bisa diarsip menjadi laporan absensi karyawan perbulan.

\section{E.2 Saran}

Dari kesimpulan yang telah dikemukakan diatas maka penulis menyarankan beberapa hal sebagai berikut:

1. Sistem informasi absensi karyawan pada PT. SAM-Jereh consortium dapat dikembangkan dengan menambah fitur fitur yang lebih lengkap lagi.

\section{REFERENSI}

[1]. Budi purnomo agung, Analisis sistem absensi.[Online] Available

[2]. Hakim, L, dan Musalini, U. 2004. Cara Mudah Memadukan Web Design dan Web Programming. Jakarta: PT Elex Media Komputindo

[3]. Indrajit. "Kajian Strategis Analisa Cost-Benefit Investasi Teknologi Informasi". Jakarta. 2010.

[4]. Jogiyanto, HM. "Analisis \& Desain Sistem Informasi”. Penerbit ANDI Offset, Yogyakarta. 2005.

[5]. Jogiyanto. "Analisa dan Desain Sistem Infomasi". 1999.

[6]. Jurnal Teknologi Informasi DINAMIK, Vol. XIV, No. 2, Juli 2009.

[7]. Sutanta, Edi. "Basis Data Dalam Tinjauan Konseptual". CV. Andi, Yogyakarta. 2011.

[8]. Witarto. "Memahami sistem Informasi". Bandung. Informatika. 2004. 